\title{
M.Y.O.B.*
}

\section{André Simon}

Dr. med., Facharzt für Allgemeine Innere Medizin, Mitglied FMH

Dr. med. André Simon Facharzt für Allgemeine Innere Medizin Dörflistrasse 14

CH-8057 Zürich

andre.simon[at]hin.ch
An ancient Chinese fable describes a despondent horse, which lies down, and no longer wants to learn to get up. The desperate owner, after trying everything, calls Mǎzhìliáo (a horse healer).

After the profound examination, the horse healer explains: "Such cases are very serious. Let's try with these plants for a couple of days. If it does not react, it will be necessary to bring the horse down.» A pig eavesdrops, and runs to the horse: "Get up, otherwise it ends badly!!!» The horse turns its head on the other side.

A day after, the horse healer returns and administers the medicinal plants again and declares: «The horse doesn't react: we should wait a little longer, but I don't think there is anything we can do.» Again, the pig has heard everything and runs to the horse: «You MUST get up!!!» But the horse remains immovable.

On the third day, the horse healer verifies the progress. "Give me the rifle: it's time to put down that poor beast.» The pig runs desperately to the horse: «Please you have to react, they're coming to kill you!» The horse rises abruptly and starts to run, jumping over the obstacles.

The owner was delighted and praised the horse healer: «Thank you, thank you!!! You are a wonderful healer; you did a miracle! We absolutely have to have a big festivity: Come on, let's kill the pig!»

Moral: Always mind your own business. ${ }^{*}$ In this way you'll stay busy all the time, and not meddle with other men's concerns.

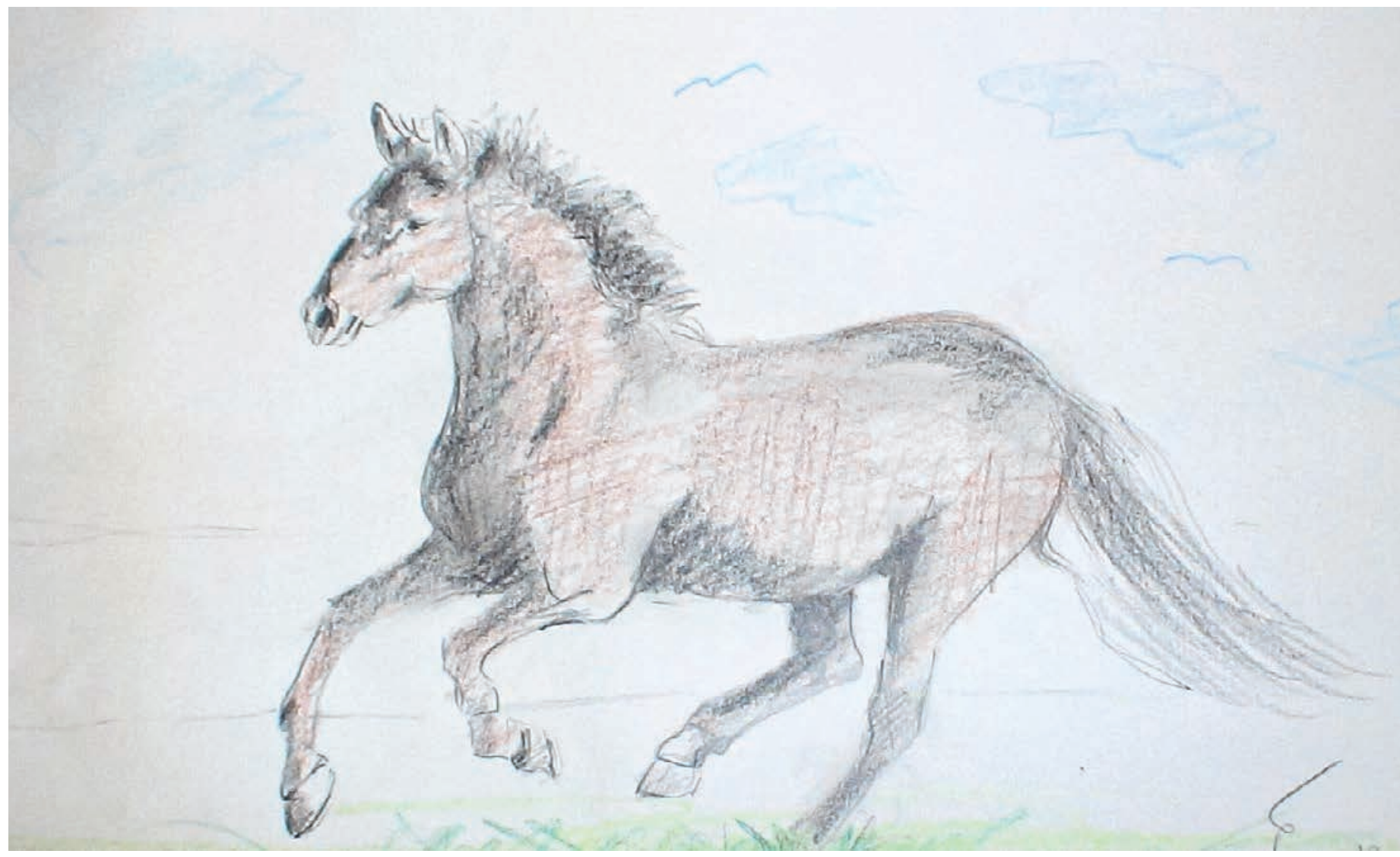

(C) André Simon 